\title{
Teknik Menulis Artikel Konseptual
}

\author{
Herianto \\ STKIP YAPTI Jeneponto
}

\begin{abstract}
Abstrak
Artikel adalah karangan faktual secara lengkap dengan panjang tertentu yang dibuat untuk dipublikasikan di media online maupun cetak (melalui jurnal, koran, majalah, buletin, blog, preprint dsb) dan bertujuan menyampaikan gagasan dan fakta yang dapat meyakinkan, mendidik, dan menghibur. Artikel konseptual sering diistilahkan dengan artikel hasil pemikiran atas suatu permasalah yang dituangkan dalam bentuk tulisan, dengan menggunakan bahasa baku (sesuai Ejaan Yang Disempurnakan atau EYD). Struktur penulisan artikel konseptual yaitu: 1) judul artikel; 2) kepemilikan atau nama penulis; 3)pendahuluan; 4) bagian inti atau isi artikel; 5) penutup; dan 6) Bibliography.
\end{abstract}

\section{Pendahuluan}

Menulis merupakan sebuah kegiatan yang dilakukan dalam menuangkan gagasan atau ide dan perasaan seseorang yang diungkapkan melalui bahasa tulis yang diharapkan bisa dipahami oleh pembaca dan pemberi fungsi alat komunikasi secara tidak langsung. Kegiatan menulis sangat penting dalam pendidikan karena dapat membantu peserta didik berlatih berfikir, mengungkapkan gagasan dan memecahkan masalah.

Dengan menulis, peserta didik mampu mengkonstruk berbagai ilmu atau pengetahuan yang dimiliki dalam sebuah tulisan, baik dalam bentuk esai, artikel,laporan ilmiah, cerpen, puisi, dan sebagainya. Penulis tidak saja harus menguasai prinsip-prinsip menulis, berwawasan dan berpengetahuan luas (memadai), menguasai kaidah-kaidah bahasa, terampil menyusun kalimat dalam sebuah paragraf, tetapi juga harus mengetahui prinsip-prinsip berpikir. Penulis harus memiliki berbagai informasi tentang apa yang akan ditulis. Informasi tersebut dapat diperoleh dari membaca dan mendengarkann dari berbagai sumber dan media informasi.

Terkhusus di perguruan tinggi, tradisi menulis menjadi hal yang mutlak khususnya dalam menulis karya tulis ilmiah. Produk keilmuan ini biasanya diperkenalkan di bangku kuliah dan terus dilatih selama proses pembelajaran. Pentingnya karya tulis ilmiah ternyata tidak hanya dirasakan oleh orang yang bersangkutan, tetapi juga oleh seluruh orang yang berkecimpung dalam hal keilmuan. Manfaatnya lebih besar dari sekadar menyimpulkan hipotesis dan menjawab permasalahan.

Istilah karya ilmiah disini adalah mengacu kepada karya tulis yangmenyusun dan penyajiannya didasarkan pada kajian ilmiah dan cara kerja ilmiah. Di lihat dari panjang pendeknya atau kedalaman uraiaan, karya tulis ilmiah dibedakan atas makalah (paper/artikel) dan laporan penelitian. 
Dalam penulisan, baik makalah maupun laporan penelitian, didasarkan pada kajian ilmiah dan cara kerja ilmiah. Penyusunan dan penyajian karya semacam itu didahului oleh studi pustaka dan studi lapangan [1].

Finoza mengklasifikasikan karangan menurut bobot isinya atas 3 jenis, yaitu: 1) karangan Ilmiah; 2)karangan semi ilmiah atau ilmiah populer; 3)karangan non ilmiah [2]. Yang tergolong ke dalam karangan ilmiah antara lain makalah, laporan, paper, artikel ilmiah, skripsi,tesis, dan disertasi; yang tergolong karangan semi ilmiah antara lain adalah artikel populer/non penelitian, editorial ,opini, feuture, reportase; yang tergolong dalam karangan non ilmiah antara lain anekdot, opini, dongeng, hikayat, cerpen, novel, roman, dan naskah drama. Ketiga jenis karangan tersebut memiliki karektiristik yang berbeda. Karangan ilmiah memiliki aturan baku dan sejumlah persyaratan khusus yang menyangkut metode dan penggunaan bahasa. Sedangkan karangan non ilmiah adalah karangan yang tidak terikat pada karangan baku;sedangkan karangan semi ilmiah berada diantara keduanya.

\section{Artikel Konseptual}

Artikel adalah karangan faktual secara lengkap dengan panjang tertentu yang dibuat untuk dipublikasikan di media online maupun cetak (melalui jurnal, koran, majalah, buletin, blog, preprint dsb) dan bertujuan menyampaikan gagasan dan fakta yang dapat meyakinkan, mendidik, dan menghibur. Artikel ilmiah yang dikenal dalam dunia akademik terbagi menjadi dua, yaitu artikel penelitian dan artikel konseptual (non penelitian).

Jika pada artikel hasil penelitian memerlukan sebuah penelitian terlebih dahulu, maka pada artikel non penelitian tidak demikian. Artikel konseptual sering diistilahkan dengan artikel hasil pemikiran atas suatu permasalah yang dituangkan dalam bentuk tulisan, dengan menggunakan bahasa baku (sesuai Ejaan Yang Disempurnakan atau EYD). Dalam upaya untuk menghasilkan artikel jenis ini penulis terlebih dahulu mengkaji sumber-sumber yang relevan dengan permasalahannya, baik yang sejalan maupun yang bertentangan dengan apa yang dipikirkannya. Sumber-sumber yang dianjurkan untuk dirujuk dalam rangka menghasilkan artikel hasil pemikiran adalah juga artikel-artikel hasil pemikiran yang relevan, hasil-hasil penelitian terdahulu, di samping teori-teori yang dapat digali dari buku-buku teks.

Bagian paling vital dari artikel hasil konseptual adalah pendapat atau pendirian penulis tentang hal yang dibahas, yang dikembangkan dari analisis terhadap pikiran-pikiran mengenai masalah yang sama yang telah dipublikasikan sebelumnya dan pikiran baru penulis tentang hal yang perlu dikaji jika memang ada.

Jadi, artikel hasil pemikiran bukanlah sekadar cuplikan dari sejumlah artikel, apalagi pemindahan tulisan dari sejumlah sumber, tetapi adalah hasil pemikiran analitis dan kritis penulisnya.

Ketentuan untuk penulisan artikel nonpenelitian pada dasarnya berlaku juga untuk penulisan makalah pendek (yaitu makalah yang panjangnya tidak lebih dari 20 halaman), kecuali dalam makalah pendek abstrak dan kata-kata kunci tidak harus ada. 
Berikut struktur penulisan artikel konseptual (non penelitian) tersebut:

1. Judul

Judul yang diambil harus sesuai dengan apa yang nantinya akan anda bahas di dalamnya. Untuk judul dapat berupa kalimat berita maupun kalimat tanya. Buatlah judul yang semenarik mungkin agar membuat orang tertarik untuk membacanya. Yang perlu diperhatikan dalam membuat judul adalah kata-kata yang digunakan harus jelas.

2. Nama Penulis (Kepemilikan)

Saat penulisan nama penulis yang harus anda ingat adalah tidak mencantumkan gelar yang anda miliki. Akan tetapi diperblehkan mencantumkan gelar kebangsawanan ataupun gelar keagamaan. Nama lembaga tempat si penulis bekerja akan ditulis pada catatan kaki di halaman pertama. Jika yang menulis artikel dua orang lebih. Maka yang ditulis namanya hanya penulis pertama disertai dengan dkk.

\section{Abstrak}

Di dalam artikel konseptual abstrak berisikan ringkasan dari artikel yang ditulis. Bukanlah berupa komentar penulis ataupun pendapat penulis. Biasanya penulisan abstrak berbeda dari bagian lain, yakni lebih menjorok ke dalam. Kata-kata yang kritis dan provokatif juga harus ada dalam abstrak.

\section{Pendahuluan}

Pada bagian pendahuluan berisikan tentang hal-hal yang dapat menarik perhatian pembaca. Yang berupa acuan terhadap permasalahan yang dibahas dengan menggunakan kalimat yang belum tuntas sehingga menarik pembaca untuk membbaca kalimat selanjutnnya. Seperti kumpulan dari berbagai argumen para tokoh.

\section{Bagian Inti}

Bagian inti membahas tentang barbagai argumen, kupasa, analisis, keputusan dan sebagainya. Atau bahkan masalah yang akan dibicarakan oleh penulis itu sendiri. Yang perlu diperhatikan adalah, ketika menulis bagian inti harus menggunakan sistematika yang logis dan urut. Dan jangan juga mengulas atau menampilkan bagian ini terlalu panjang. Yang membuat pembaca menjadi bosan.

\section{Penutup}

Penutup biasanya berisikan kesimpulan dari artikel yang telah ditulis sebelumnya, dapat pula ditulis dengan menggunakan sub bab agar memudahkan untuk membacanya. Selain kesimpulan ada juga beberapa penulis yang menambahkan saran dalam artikelnya. Tentu saran tersebut adalah sebuah pesan yang disampaikan penulis kepada yang membacanya. Maupun kepada objek yang telah ditulis. 


\section{Daftar pustaka atau Bibliografy}

Daftar pustaka merupakan kumpulan dari beberapa sumber yang telah anda ambil dan anda tulis dalam artikel ini sebelumnya. Bagian daftar pustaka terletak pada bagian paling akhir dari artikel. Yang ditulis dalam daftar pustaka adalah nama penulis yang karyanya anda jadikan sumber, judul bukunya, kota terbitan buku, percetakan yang mencetak buku tersebut. serta tahun terbit dan juga halaman. Beda lagi penulisannya jika yang anda rujuk adalah jurnal, koran, maupun sumber rujukan lainnya. masing-masing memiliki tata cara penulisan tersendiri [3].

Begitu banyak cara membuat artikel konseptual yang perlu anda perhatikan ketika anda hendak membuat artikel tersebut. paparan diatas dapat anda jadikan salah satu wawasan anda jika anda berkeinginan menulis artikel yang konseptual.

\section{Penutup}

Artikel konseptual sering diistilahkan dengan artikel hasil pemikiran atas suatu permasalah yang dituangkan dalam bentuk tulisan, dengan menggunakan bahasa baku (sesuai Ejaan Yang Disempurnakan atau EYD). Struktur penulisan artikel konseptual yaitu: 1) judul artikel; 2) kepemilikan atau nama penulis; 3)pendahuluan; 4) bagian inti atau isi artikel; 5) penutup; dan 6) Bibliography atau daftar pustaka.

\section{Bibliography}

[1] Azwardi, Menulis ilmiah: Materi Kuliah Bahasa Indonesia Umum untuk. Mahasiswa. Banda Aceh: Unsyiah, 2008.

[2] L. Finoza, Komposisi Bahasa Indonesia. Jakarta: Diksi, 2008.

[3] Jusmiana, A. (2017). DESKRIPSI KESALAHAN SISWA DALAM MENYELESAIKAN MASALAH MATEMATIKA OPERASI BENTUK ALJABAR. Pedagogy: Jurnal Pendidikan Matematika, 2(2). 